\title{
HUBUNGAN HYGIENE SANITASI MAKANAN DAN MINUMAN TERHADAP KANDUNGAN BAKTERIOLOGIS Escherichia coli PADA SOP BUAH DI WILAYAH UNIVERSITAS JENDERAL SOEDIRMAN, WILAYAH GOR SATRIA, DAN WILAYAH UNIVERSITAS MUHAMMADIYAH PURWOKERTO KABUPATEN BANYUMAS TAHUN 2016
}

\author{
Aditya Arki Wardana'), Asep Tata Gunawan' ${ }^{2)}$, Nur Hilal ${ }^{3)}$ \\ Jurusan Kesehatan Lingkungan, Politeknik Kesehatan Kemenkes Semarang, \\ Jl.Raya Baturaden KM 12 Purwokerto, Indonesia
}

\begin{abstract}
Abstrak
Hygiene sanitasi makanan adalah upaya untuk mengendalikan faktor makanan, orang, tempat dan perlengkapannya yang dapat atau mungkin dapat menimbulkan penyakit atau gangguan kesehatan. Tujuan penelitian ini adalah untuk mengetahui adanya hubungan hygiene sanitasi makanan dan minuman terhadap kandungan bakteriologis Escherichia coli pada sop buah tahun 2016. Jenis penelitian adalah observasional dengan pendekatan cross sectional. Hasil analisis bivariat menunjukkan variabel yang berhubungan dengan kandungan bakteriologi E.coliyaitu variabel perilaku penjamah makanan ( $p$ value=0,032), bahan baku sop buah ( $p$ value= 0,032), dan es batu ( $p$ value= 0,008),. Variabel personal hygiene penjamah makanan, perilaku penjamah makanan, pemilihan bahan makanan, penyimpanan bahan makanan, pengolahan makanan, pengangkutan makanan, penyajian makanan, peralatan, lokasi, dan bahan tidak ada hubungan yang signifikan. Kesimpulan dari penelitian ini adalah dari 31 sampel sop buah yang diperiksa, 30 sampel positif E.colidan variabel yang berhubungan adalah perilaku penjamah, bahan baku sop buah dan es batu.
\end{abstract}

Kata kunci $\quad$ : hygiene sanitasi makanan minuman, , e.coli, kesehatan lingkungan

\begin{abstract}
Hygiene food sanitation is the effort to control food, human, place and equipment factors which can or may cause disease and health problems. The purpose of this research is to find out the correlation between hygiene food and drink sanitation towards bacteriology escherichia coli containing in fruit soup in 2016. The type of this research is observational with cross sectional. Bivariate analysis result shows the variables which was related with bacteriology E.coliwere behavior of food handlers ( $p$ value $=0,032$ ), fruit soup food stuffs ( $p$ value $=0,032$ ), and ice block variable ( $p$ value $=0,008$ ). Variables of personal hygiene of food handlers, behavior of food handlers, selection of food stuffs, storage of food stuff, food making, food transportation, food serving, equipment, location, and food stuffs had no significant correlation. The conclusion of this research is from 31 fruit soup samples which were examined, 30 samples positive contained E.coliand variable related were behavior of food handlers, fruit soup food stuffs and ice block.
\end{abstract}

Keywords $\quad$ : Hygiene food and drink sanitation, E. coli, environmental health

I. PENDAHULUAN

Undang-undang Nomor 36 Tahun 2009 tentang Kesehatan, salah satu upaya preventif untuk mewujudkan tujuan pembangunan kesehatan adalah melalui kegiatan penyehatan makanan (pasal 48 ayat (1) poin ke 15). Untuk mewujudkan kegiatan penyehatan makanan ini dilaksanakan melalui upaya sanitasi makanan.

Menurut Keputusan Menteri Kesehatan No. 715, hygiene sanitasi makanan adalah upaya untuk mengendalikan faktor makanan, orang, tempat dan perlengkapannya yang dapat atau mungkin dapat menimbulkan penyakit atau gangguan kesehatan.

Tujuan penelitian ini adalah untuk mengetahui adanya hubungan hygiene sanitasi makanan dan

1) Email : adityaarkiwardana@yahoo.co.id

2) Email : aseptatagunawan@yahoo.co.id

3) Email : inung.nh@gmail.com minuman terhadap kandungan bakteriologis Escherichia coli pada sop buah tahun 2016.

\section{BAHAN DAN METODE}

Jenis penelitian adalah observasional dengan pendekatan cross sectional untuk melihat gambaran kondisi hygiene sanitasi dan kandungan bakteri Escherichia coli yang terdapat dalam sop buah. Populasi adalah 31 pedagang dan pengambilan sampel yaitu total sampling. Variabel yang diteliti meliputi personal hygiene penjamah makanan, perilaku penjamah makanan, pemilihan bahan makanan, penyimpanan bahan makanan, pengolahan makanan, penyimpanan makanan jadi, pengangkutan makanan, penyajian makanan, peralatan, lokasi, 
bahan, dan es batu, dengan uji chi square dengan $\alpha$ 0,05 .

\section{HASIL DAN PEMBAHASAN}

\section{Univariate}

Berdasarkan hasil penelitian menunjukkan bahwa 30 sampel sop buah (96.7\%) tidak memenuhi syarat (positif mengandung E.coli), dan 1 sampel sop buah (3.3\%) telah memenuhi syarat (negatif mengandung E.coli.

Berdasarkan hasil penelitian menunjukkan bahwa 4 sampel sumur yang diperiksa (100\%) tidak memenuhi syarat (positif mengandung E.coli)

Berdasarkan hasil penelitian menunjukkan bahwa Personal Hygiene penjamah makanan dalam proses pengolahan sop buah yang tidak memenuhi persyaratan terdapat 31 responden (100\%).

Berdasarkan hasil penelitian menunjukkan bahwa responden dengan perilaku tidak memenuhi syarat lebih besar (96.7\%) dibandingkan dengan perilaku menjamah makanan yang memenuhi syarat (3,3\%).

Berdasarkan hasil penelitian menunjukkan bahwa keseluruhan responden dalam proses pemilihan bahan baku telah memenuhi syarat yaitu sebesar 31 responden (100\%).

Berdasarkan hasil penelitian menunjukkan bahwa responden dengan penyimpanan bahan baku tidak memenuhi syarat lebih besar (67.7\%) dibandingkan dengan responden dengan penyimpanan bahan baku yang memenuhi syarat. (32,3\%).

Berdasarkan hasil penelitian menunjukkan bahwa responden dengan pengolahan bahan tidak memenuhi syarat lebih kecil (41.9\%) dibandingkan dengan responden dengan pengolahan bahan yang memenuhi syarat. $(58,1 \%)$.

Berdasarkan hasil penelitian menunjukkan bahwa responden dengan penyimpanan sop buah tidak memenuhi syarat lebih besar (54,8\%) dibandingkan dengan responden dengan penyimpanan penyimpanan sop buah yang memenuhi syarat. (45,2\%\%).

Berdasarkan hasil penelitian menunjukkan bahwa responden dengan pengangkutan bahan siap saji tidak memenuhi syarat kecil (19,4\%) dibandingkan dengan responden dengan pengangkutan bahan siap saji yang memenuhi syarat. (80,6\%).

Berdasarkan hasil penelitian menunjukkan bahwa responden dengan penyajian sop buah tidak memenuhi syarat lebih besar (67.7\%) dibandingkan dengan responden dengan penyajian sop buah yang memenuhi syarat. (32,3\%).

Berdasarkan hasil penelitian menunjukkan bahwa responden dengan peralatan pengolahan sop buah yang tidak memenuhi syarat lebih kecil (35,5\%) dibandingkan dengan responden peralatan pengolahan sop buah yang memenuhi syarat. (64,5\%).

Berdasarkan hasil penelitian menunjukkan bahwa keseluruhan responden dalam lokasi penjualan tidak memenuhi syarat (100\%).

Berdasarkan hasil penelitian menunjukkan bahwa responden dengan bahan baku sop buah yang tidak memenuhi syarat lebih kecil (3,2 \%) dibandingkan dengan responden dengan bahan baku sop buah yang memenuhi syarat. (96,8\%).

Berdasarkan hasil penelitian menunjukkan bahwa responden dengan bahan baku es batu yang tidak memenuhi syarat lebih besar (87,1 \%) dibandingkan dengan responden dengan bahan baku es batu yang memenuhi syarat. (12,9\%).

\section{Bivariate}

Berdasarkan hasil penelitian bahwa variable personal hygiene penjamah tidak bisa dilakukan pengujian spss menggunakan uji chi square karena keseluruhan pedagang sop buah tidak memenuhi syarat (100\%). Pada dasarnya sebagian besar responden sudah cukup baik dalam melakukan praktik personal hygiene, namun karena sebagian besar pedagang menggunakan air sumur untuk melakukan kegiatan cuci tangan, maka tangan pedagang sop buah tersebut juga terkontaminasi bakteri Escherichia coli yang berasal dari sumur yang digunakan oleh responden. Untuk itu meskipun tidak ada hubungan yang bermakna antara personal hygiene dengan kandungan bakteri Escherichia coli, tetapi terdapat faktor resiko yang dapat mengkontaminasi sop buah tersebut. Namun para pedagang sop buah juga tetap harus memperhatikan personal hygiene masingmasing, karena kontaminasi bakteri Escherichia coli dapat berasal dari mana saja.

Berdasarkan hasil uji chi square diperoleh nilai $p$ value $=0.032(p>0,05)$ dengan demikian ada hubungan yang bermakna antara perilaku penjamah makanan dengan kandungan bakteriologi E.coli. Berdasarkan hasil wawancara dengan menggunakan kuesioner pada dasarnya sebagian besar responden telah berperilaku baik, hanya saja para penjamah makanan tersebut masih banyak yang tidak mengikat rambut atau menutup kepala mereka pada saat mengolah makanan. Menurut Keputusan Menteri Kesehatan Republik Indonesia Nomor 942 Tahun 2003 Tentang Pedoman persyaratan hygiene sanitasi makanan jajanan bahwa penjamah makanan yang memenuhi syarat yaitu tidak menderita penyakit mudah menular misalnya seperti batuk, pilek, influenza, diare dan penyakit perut sejenisnya. Menutup luka, menjaga kebersihan tangan, menjaga kebersihan kuku, menjaga kebersihan pakaian, memakai celemek, memakai penutup kepala, mencuci tangan setiap kali hendak menangani makanan, menjamah makanan harus memakai alat/ perlengkapan atau dengan alas tangan, tidak sambil merokok, tidak sambil menggaruk anggota badan 
(telinga, hidung, mulut dan bagian lainnya), tersedia sabun dan tissue.

Berdasarkan hasil penelitian bahwa variable pemilihan bahan makanan tidak bisa dilakukan pengujian spss menggunakan uji chi square karena keseluruhan pedagang sop buah telah memenuhi syarat (100\%). Dari hasil kunjungan lapangan yang dilakukan oleh peneliti, keseluruhan pedagang sop buah telah memenuhi syarat kesehatan dalam pemilihan bahan baku, meliputi buah yang digunakan berasal dari daerah setempat, penampilannya baik dan tidak rusak, kondisi fisik sudah cukup tua (matang). Hal ini telah sesuai dengan Peraturan Menteri Kesehatan RI No. 942 Tahun 2003 tentang Makanan Jajanan, menyatakan bahwa bahan makanan hendaknya diperoleh dari penyedia bahan makanan yang terdaftar dan berizin, harus dalam keadaan baik mutunya, segar dan tidak busuk. Meskipun semua kriteria telah memenuhi syarat tetapi pencemaran bakteri Escherichia coli masih tetap dapat terjadi, seperti bahan yang digunakan telah terjadi pencemaran saat melakukan perjalanan yang panjang dari penyedia sampai ke tangan konsumen. Selain itu penggunaan pupuk kompos yang berasal dari kotoran hewan juga dapat mengkontaminasi tanaman tersebut.. Bahan makanan yang dijual mengalami perjalanan yang panjang melalui jaringan perdagangan pangan. Banyak yang tidak mengetahui dari mana sumber makanan tersebut berasal sehingga sumber makanan yang baik sering kali tidak mudah ditemukan dan mempengaruhi kualitasnya. Semua bahan olahan dalam kemasan harus terdaftar di Departemen Kesehatan RI, tidak kadaluwarsa, tidak cacat atau tidak rusak Mutu dan keamanan pangan suatu produk pangan sangat tergantung pada mutu dan keamanan bahan mentahnya. Oleh karena itu, untuk dapat mengahasilkan produk pangan yang bermutu dan aman dikonsumsi, bahan mentah harus dipilih terlebih dahulu (BPOM, 2002).

Berdasarkan hasil uji chi square diperoleh nilai $\mathrm{p}$ value $=0.677(\mathrm{p}>0,05)$ dengan demikian tidak ada hubungan yang bermakna antara penyimpanan bahan baku dengan kandungan bakteriologi E.coli. Hasil analisis ini sejalan dengan penelitian yang dilakukan oleh Yunaenah (2009), hasil uji statistik antara penyimpanan bahan makanan dan kontaminasi E.colidiperoleh nilai $\mathrm{P}=0,366(\mathrm{P}>0,05)$ dan $\mathrm{OR}$ $=2,031$ maka dapat disimpulkan tidak ada hubungan yang bermakna antara kedua variabel tersebut. Pada dasarnya para pedagang sop buah dalam kategori penyimpanan bahan baku sudah cukup baik, salah satunya yaitu sebesar 80,6\% pedagang melakukan pencucian bahan baku buah segar mengunakan air yang mengalir sebelum dilakukan penyimpanan. Namun, karena sebagian besar pedagang menggunakan air sumur dalam pengolahannya maka buah tersebut juga akan terkontaminasi oleh bakteri Escherichia coli. Oleh sebab itu, meskipun tidak ada hubungan yang bermakna antara kedua variabel tersebut namun faktor resiko masih tetap ada.

Berdasarkan hasil uji chi square diperoleh nilai $p$ value $=0.419(p>0,05)$ dengan demikian tidak ada hubungan yang bermakna antara pengolahan bahan baku dengan kandungan bakteriologi E.coli. Hasil analisis ini sejalan dengan penelitian yang dilakukan oleh Yunaenah (2009), hasil uji statistik antara pengolahan makanan dan kontaminasi E.colidiperoleh nilai $\mathrm{P}=0,973 \quad(\mathrm{P}>0,05)$ dan $\mathrm{OR}$ =1,026 maka dapat disimpulkan tidak ada hubungan yang bermakna antara kedua variabel tersebut. Meskipun hasil analis data mendapatkan hasil tidak ada hubungan yang bermakna, akan tetapi pada dasarnya perilaku responden dalam pengolahan bahan baku sop buah sudah cukup baik seperti menyortir bahan yang akan diolah, memotong buah dalam keadaan kecil sehingga mudah dikonsumsi, membuang bagian buah yang rusak atau bernoda. Namun sebesar $64,5 \%$ pedagang mencuci buah yang akan digunakan tersebut menggunakan air sumur. Sedangkan dari hasil pemeriksaan terhadap beberapa sumur di wilayah tersebut, semua sumur yang digunakan oleh para pedagang sop buah tidak memenuhi syarat sehingga dapat mengkontaminasi buah yang akan diolah tersebut.

Berdasarkan hasil uji chi square diperoleh nilai $p$ value $=0.548(p>0,05)$ dengan demikian tidak ada hubungan yang bermakna antara penyimpanan sop buah dengan kandungan bakteriologi E.coli. Hasil analisis ini sejalan dengan penelitian yang dilakukan oleh Yunaenah (2009), hasil uji statistik antara pengolahan makanan dan kontaminasi E.colidiperoleh nilai $\mathrm{P}=0,973 \quad(\mathrm{P}>0,05)$ dan $\mathrm{OR}$ $=1,026$ maka dapat disimpulkan tidak ada hubungan yang bermakna antara kedua variable tersebut.Meskipun hasil analis data mendapatkan hasil tidak ada hubungan yang bermakna, akan tetapi pada dasarnya perilaku responden dalam pengolahan bahan baku sop buah sudah cukup baik seperti menyortir bahan yang akan diolah, memotong buah dalam keadaan kecil sehingga mudah dikonsumsi, membuang bagian buah yang rusak atau bernoda. Namun sebesar $64,5 \%$ pedagang mencuci buah yang akan digunakan tersebut menggunakan air sumur. Sedangkan dari hasil pemeriksaan terhadap beberapa sumur di wilayah tersebut, semua sumur yang digunakan oleh para pedagang sop buah tidak memenuhi syarat sehingga dapat mengkontaminasi buah yang akan diolah tersebut. Hasil analisis ini sejalan dengan penelitian yang dilakukan oleh Djamaludin Musa (2013), hasil uji statistik antara penyimpanan makanan jadi dan kontaminasi E.colidiperoleh nilai $\mathrm{P}=0,548(\mathrm{P}>0,05)$ maka dapat disimpulkan tidak ada hubungan yang bermakna antara kedua variabel tersebut.permasalahan yang ditemukan oleh peneliti yaitu penyimpanan bahanbahan yang siap diracik tidak mempunyai wadah sesuai jenisnya dan dapat terjangkau oleh lalat. Hal ini tidak sesuai dengan Ditjen PPM \& PLP 
(1998. H. 22) menyatakan bahwa tempat penyimpanan makanan harus disimpan dalam wadah yang terpisah sesuai dengan jenis makanan dan disimpan pada suhu 10oc. Menurut Arisman (2009. h. 163) penyimpanan bahan makanan harus selalu terpelihara dan dalam keadaan bersih. Penempatan bahan makanan harus terpisah sesuai dengan jenis bahan makanan masing-masing. Penyimpanan makanan jadi harus terlindung dari debu, bahan kimia berbahaya, serangga, dan hewan lainnya.

Berdasarkan hasil uji chi square diperoleh nilai $\mathrm{p}$ value $=0.194(\mathrm{p}>0,05)$ dengan demikian tidak ada hubungan yang bermakna antara pengangkutan bahan siap saji dengan kandungan bakteriologi E.coli. Hasil analisis ini sejalan dengan penelitian yang dilakukan oleh Yunaenah (2009), hasil uji statistik antara pengangkutan makanan dan kontaminasi E.coli diperoleh nilai $\mathrm{P}=0,115(\mathrm{P}>0,05)$ dan $\mathrm{OR}=2,667$ maka dapat disimpulkan tidak ada hubungan yang bermakna antara kedua variable tersebut. Pengangkutan makanan dilakukan dengan tujuan memindahkan makanan untuk disimpan atau langsung disajikan. Alat yang digunakan untuk pengangkutan buah menggunakan wadah yang terbuat dari plastik. Sebagian besar pedagang tidak menggunakan wadah per masing-masing jenis buah, selain itu wadah tersebut tidak menggunakan tutup sehingga memudahkan lalat atau binatang pengganggu lainnya untuk hinggap di buah tersebut. Agar makanan yang diolah tidak terkontaminasi, perlu dilakukan oleh tenaga pengangkut yang mempunyai perilaku dan personal hygiene yang baik, selain itu alat untuk untuk mengangkut menggunakan peralatan yang tidak mudah berkarat, bersih dan berpenutup. Selain itu teknik pengangkutan penting agar makanan harus dilakukan dengan mengambil jakur yang dekat dan tidak melewati tempat yang kotor dan memungkinkan terjadinyakontaminasi.

Berdasarkan hasil uji chi square diperoleh nilai $p$ value $=0.742(p>0,05)$ dengan demikian tidak ada hubungan yang bermakna antara penyajian sop buah dengan kandungan bakteriologi E.coli. Hal ini sejalan dengan penelitian yang dilakukan oleh Djamaludin Musa (2013), Hasil uji statistik dengan uji Fisher menunjukkan nilai $\mathrm{p}=0,227$, artinya tidak ada hubungan yang bermakna antara kedua variabel tersebut. Penyajian makanan merupakan rangkaian akhir dari perjalanan makanan. Makanan yang disajikan adalah makanan yang siap santap. Penyajian makanan pada umumnya para pedagang langsung menggunakan wadah seperti gelas plastik, sehingga buah yang telah dipotong langsung dimasukkan ke dalam wadah tersebut dan disimpan didalam kulkas. Namun sebagian pedagang menggunakan wadah untuk menempatkan buah tersebut. Menurut Departemen Kesehatan RI Tahun 2004, dalam penyajian makanan matang harus memperhatikan prinsip penyajian, yaitu tempat penyajian makanan harus bersih dan tertutup, cara pengambilan makanan harus menggunakan peralatan yang bersih. Agar tidak terjadi kontaminasi sebaiknya para pedagang juga menggunakan sarung tangan yang bersih yang khusu untuk menyajikan sop buah tersebut. dan untuk menghindari pembusukan buah yang sudah siap disajikan, sebaiknya dimasukkan ke dalam kulkas sehingga terjamin kebersihannya. Wadah yang telah digunakan untuk menyajikan sop buah harus selalu dibersihkan sebelum digunakan kembali untuk menyajikan sop buah tersebut.

Berdasarkan hasil uji chi square diperoleh nilai $\mathrm{p}$ value $=0.355(\mathrm{p}>0,05)$ dengan demikian tidak ada hubungan yang bermakna antara peralatan pengolahan dengan kandungan bakteriologi E.coli. Hal ini tidak sejalan dengan penelitian yang dilakukan oleh Libriliana (2012), hasil uji statistik antara sanitasi alat dengan keberadaan E.coli diperoleh $\mathrm{p}$ value sebesar $0,028<\mathrm{p}(0,05)$, dengan demikian ada hubungan yang bermakna antara sanitasi alat makan dengan kandungan bakteriologis E.coli. Permasalahan ditemukan di lapangan yaitu pedagang sop buah tidak langsung mencuci peralatan setelah digunakan, mereka hanya membersihkan alat tersebut apabila toko akan tutup. Kadang-kadang untuk membantu proses pembersihan peralatan diperlukan bantuan kain lap/serbet. Serbet makan yang digunakan bersamaan dengan penyajian makanan harus bersih, kering, dan tidak digunakan untuk keperluan lain. Serbet atau spon yang digunakan untuk melap peralatan dapur yang secara langsung bersentuhan dengan makanan harus bersih dan sering dicuci serta disanitasi dengan bahan sanitaiser yang sesuai. Peralatan dalam pengolahan makanan minuman berperan penting, bahwa sanitasi makanan merupakan suatu tindakan pencegahan yang menitikberatkan pada kegiatan dan tindakan yang dilakukan untuk mengamankan makanan dari segala bentuk bahaya yang dapat mengganggu kesehatan, mulai dari pengadaan bahan makanan sampai pada saat makanan dikonsumsi oleh konsumen.

Berdasarkan hasil penelitian menunjukkan bahwa variabel lokasi penjualan sop buah tidak bisa dilakukan pengujian spss menggunakan uji chi square karena keseluruhan pedagang sop buah tidak memenuhi syarat (100\%). Dari hasil observasi yang dilakukan oleh peneliti terhadap 31 pedagang sop buah, keseluruhan responden tidak memenuhi kriteria. Hal-hal yang paling tidak banyak dipenuhi oleh pedagang yaitu pedagang sop buah yaitu lokasi penjualan sop buah berada di samping jalan raya dan tidak menggunakan tempat sampah yang tertutup. Dalam keadaan tersebut kemungkinan makanan tercemar sangat besar. Tempat sampah yang terbuka sangat mengundang vektor atau binatang pengganggu seperti lalat. Lalat yang hinggap di tempat sampah tersebut telah membawa jutaan kuman penyakit yang kemudian hinggap ke makanan sehingga makanan tersebut terkontaminasi 
bakteri salah satunya yaitu bakteri E.coli. Meskipun sarana pembuangan tempat sampah tidak memenuhi syarat tetapi sampah yang ada selalu dibuang setiap hari sehingga tidak menjadi perindukan serangga. Artinya dalam penelitian ini sarana pembuangan sampah tidak memiliki pengaruh terhadap kontaminasi bakteri E.coli.

Berdasarkan hasil uji chi square diperoleh nilai $\mathrm{p}$ value $=0.032 \quad(\mathrm{p}<0,05)$ dengan demikian ada hubungan yang bermakna antara bahan pembuatan sop buah dengan kandungan bakteriologi E.coli. Permasalahan yang ditemukan oleh peneliti terhadap bahan makanan terdapat beberapa variabel yang memenuhi syarat yaitu buah yang digunakan sudah dalam keadaan matang, tidak layu, kondisi fisik sirup dan susu yang digunakan tidak rusak, terdapat label kadaluwarsa dan terdaftar pada Departemen Kesehatan RI. Menurut Permenkes RI No. 942 Tahun 2003 Tentang Makanan Jajanan, menyatakan bahwa bahan makanan hendaknya diperoleh dari penyedia bahan makanan yang terdaftar dan berizin, harus dalam keadaan baik mutunya, segar dan tidak busuk. Semua bahan olahan dalam kemasan harus terdaftar di Departemen Kesehatan RI, tidak kadaluwarsa, tidak cacat atau tidak rusak. Para pedagang sop buah di lokasi penelitian umumnya membeli bahan makanan di pasar tradisional. Penting untuk dipahami bahwa persediaan bahan baku harus cukup tersedia dengan kualitas yang baik. Penyimpanannya harus pada tempat yang cukup luas dengan kondisi yang baik, terlindung dari hewan peliharaan dan lingkungan yang kotor. Sejauh mungkin diusahakan agar penyediaan makanan harus teratur penggunaannya dan harus dicegah penyimpanan makanan dalam jumlah yang berlebihan.

Berdasarkan hasil uji chi square diperoleh nilai $\mathrm{p}$ value $=0.008(\mathrm{p}<0,05)$ dengan demikian ada hubungan yang bermakna antara bahan baku es batu dengan kandungan bakteriologi E.coli. Bahan baku pembuatan es batu yang digunakan oleh pedagang berasal dari air mentah yang berasal dari air sumur dan air ledeng. Para pedagang tidak melakukan pemasakan air tersebut dikarenakan untuk menghemat biaya produksi. Bakteri pathogen yang biasa hidup pada manusia dapat bertahan sampai beberapa bulan pada temperature titik beku. Pada umumnya batas daerah temperature bagi kehidupan mikroba antara $0^{\circ} \mathrm{C}-90^{\circ} \mathrm{C}$ (Lud Waluyo, 2005, h. 123). Menurut Dirjen PP\&PL (2010, h.249) bakteri tidak akan mati selama proses pembekuan, tetapi berhenti pertumbuhannya dalam keadaan tidur sementara. Mikroba dapat dimatikan dengan cara memasak makanan tersebut pada suhu $\pm 100^{\circ} \mathrm{C}$. Proses penyimpanan pada suhu rendah tidak dapat digunakan untuk menginaktivasi atau mematikan mikroba karena mikroorganisme dianggap dorman dan tidak menunjukan aktivitas metabolik yang dapat diditeksi. (Pelczar, 1988, h.470).

\section{SIMPULAN DAN SARAN}

\section{Simpulan}

Kesimpulan dari penelitian ini adalah dari 31 sampel sop buah yang diperiksa, 30 sampel positif E.coli dan variabel yang berhubungan adalah perilaku penjamah, bahan baku sop buah dan es batu, sedangkan variabel personal hygiene penjamah makanan, perilaku penjamah makanan, pemilihan bahan makanan, penyimpanan bahan makanan, pengolahan makanan, pengangkutan makanan, penyajian makanan, peralatan, lokasi, dan bahan tidak ada hubungan yang signifikan

\section{Saran}

Peneliti menyarankan agar sumber air yang digunakan berasal dari tempat yang terlindung dari pencemaran dan melakukan pengolahan terhadap air tersebut.

\section{DAFTAR PUSTAKA}

Anwar, dkk. 1994. Pedoman Bidang Studi Makanan dan Minuman Pada Instansi Tenaga Sanitasi. Jakarta.

Arisman. 2009. Keracunan Makanan: Buku Ajar ilmu Gizi. Jakarta : EGC

Australian Government, National Health and Medical Research Council, 2003. Review of Coliforms As Microbial Indicators of Drinking Water Quality. at : http://www.nhmrc.gov.au/_files_nhmrc/pub lications/attachments/eh32.pdf (diakses pada 03 Januari 2016, pukul 12.23)

Buku Profil Kesehatan Provinsi Jawa Tengah. 2012. From

http://www.depkes.go.id/resources/downloa d/profil/PROFIL_KES_PROVINSI_2012/1 3_Profil_Kes.Prov.JawaTengah_2012.pdf (diakses pada 15 Desember 2015, pukul 18.43)

BPOM, 2002. Panduan Pengolahan Pangan Yang Baik Bagi Industri Rumah Tangga. Deput Bidang Pengawasan Keamanan Pangan dan Bahan Berbahaya. Direktotat Surveilan dan Penyuluhan Keamanan Pangan.

Chandra, Budiman. 2006. Pengantar Kesehatan Lingkungan. Jakarta : EGC Departemen Kesehatan RI. Direktorat Jenderal Pengendalian Penyakit Dan Penyehatan Lingkungan (DIT.JEN.PP\&PL), 1998. Pedoman Pembinaan dan Pengawasan Sanitasi Makanan, Jakarta : DIT.JEN.PP\&PL 
Departemen Kesehatan RI. Direktorat Jenderal Pengendalian Penyakit Dan Penyehatan Lingkungan (DIT.JEN.PP\&PL), 1998. Jasaboga Untu Umum, Jakarta : DIT.JEN.PP\&PL

Departemen Kesehatan RI. Direktorat Jenderal Pengendalian Penyakit Dan Penyehatan Lingkungan (DIT.JEN.PP\&PL), 2004. Hygiene Sanitasi Makanan dan Minuman. Jakarta : DIT.JEN.PP\&PL

Departemen Kesehatan RI, 2000. Prinsip-Prinsip Hygiene dan Sanitasi Makanan. Jakarta : Depkes RI

F.G. Winarno. 2004. Keamanan Pangan Jilid 1. Bogor: M-Brio Press

Hiasinta Purnawijayanti. 2001. Sanitasi, Hygiene, dan keselamatan Kerja dalam Pengolahan Makanan. Yogyakarta : Kanisius

Jernita Sinaga. 2011. Hygiene Sanitasi Dan Pemeriksaan Kandungan Eschericia coli Pada Sop Buah Yang Dijual Di Pasar Kabanjahe Kabupaten Karo Tahun 2011. Skripsi. Medan, Universitas Sumatera Utara Fakultas Kesehatan Masyarakat. at: http://repository.usu.ac.id/

bitstream/123456789/28057/4/Chapter\%20I I.pdf ( diakses pada 23 Januari 2016, pukul 07.54)

Lud Waluyo. 2007. Mikrobiologi Umum. Malang : UMM-Press.

Mukono. 2000. Prinsip Dasar Kesehatan Lingkungan Edisi Pertama. Surabaya : Airlangga University Press

2006. Prinsip Dasar Kesehatan Lingkungan Edisi Kedua. Surabaya : Airlangga University Press

Nurwantoro., dan Abbas Siregar Djarijah, 1997. Mikrobiologi Pangan Hewani-Nabati. Yogyakarta : Kanisius

Pelczar, Michael. 1988. Dasar-dasar Mikrobiologi. Jakarta : UI-Press.

Restuti. 2013. Studi Komparasi Total Bakteri Coliform Bahan Baku Es Batu Dan Es Batu Pada Industri Rumah Tangga Di Kelurahan Mersi Kecamatan Purwokerto Timur. Purwokerto: Kementrian Kesehatan RI Politeknik Kesehatan Semarang Jurusan Kesehatan Lingkungan Purwokerto.
Ricki M. Mulia. 2005. Kesehatan Lingkungan. Yogyakarta: Graha Ilmu

Riyan Ningsih. 2014. Penyuluhan Hygiene Sanitasi Makanan Dan Minuman, Serta Kualitas Makanan Yang Dijajakan Pedagang Di Lingkungan SDN Kota Samarinda. Jurnal Kesmas at http://journal.unnes.ac.id/nju/index.php/ke mas (diakses pada : 31 Januari 2016, Pukul 20.46 )

SNI 01- 3839-1995 tentang Es Batu

Sri Winarsih. 2008. pengetahuan sanitasi dan aplikasinya. Semarang : CV Aneka Ilmu

Titiek F Djafar., dan Siti Rahayu. 2007. Cemaran Mikroba Pada Produk Pertanian, Penyakit Yang Ditimbulkan dan Pencegahannya. at : http://pustaka.litbang.pertanian.go.id/publik asi/p3262073.pdf (diakses pada : 12 Februari 2016 Pukul 21.17)

Tri Cahyono. 2014. Pedoman Penulisan Proposal Penelitian dan Karya Tulis Ilmiah/Skripsi Edisi Revisi Ketiga, Purwokerto: Kementrian Kesehatan RI Politeknik Kesehatan Semarang Jurusan Kesehatan Lingkungan Purwokerto

Vimalan Parthipan. 2013. Analisa Bakteri Coliform Dan Identifikasi Escherichia coli Pada Sop Buah Yang Dijual Di Jalan Dr. Mansur Medan Tahun 2013. Skripsi. Medan, Universitas Sumatera Utara Fakultas Kesehatan Masyarakat. at : http://repository.usu.ac.id/handle/12345678 9/40571 (diakses pada 30 Desember 2016, pukul 13.51)

Volk, Wheeler M., 1984. Mikrobiologi Dasar, Penterjemah : Markham, Penerbit Erlangga, Jakarta.

Wahyu Aji Utomo. 2008. Identifikasi Salmonella sp Pada Sop Buah Yang Dijual Di Daerah Pleburan Semarang. at : http://digilib.unimus.ac.id/gdl.php?mod=br owse\&op=read\&id=jtptunimus-gdl-s12008-wahyuajiut-242. (diakses pada 17 Februari 2016, pukul 21.10)

World Health Organization (WHO). 2000. Penyakit Bawaan Makanan Fokus Pendidikan Kesehatan. Jakarta : EGC

, 2011. Enterohaemorhagic Escherichia Coli. at http://www.who.int/mediacentre/factsheets/ 
fs125/en/index.html (diakses pada 25 November 2015 pukul 21.10).

Yunaenah. 2009. Kontaminasi E.Coli Pada Makanan Jajanan Di Kantin Sekolah Dasar Wilayah Jakarta Pusat Tahun 2009. at: http://lib.ui.ac.id/file?file=digital/20281615 -T\%2021801-Kontaminasi\%20ecolifull\%20text.pdf (Diakses pada 11 Juni 2016, pukul 08.20) 